.. Yapici: Experimental Study on Combustion Properties and Thermo-Gravimetric Analyses...

Fatih Yapici $^{1}$

\title{
Experimental Study on Combustion Properties and Thermo-Gravimetric Analyses of Oriented Strand Board (OSB)
}

\section{Eksperimentalna istraživanja svojstava gorenja i termogravimetrijska analiza ploča iverica s usmjerenim makroiverjem (OSB)}

Original scientific paper • Izvorni znanstveni rad

Received-prispjelo: 20. 2. 2019.

Accepted-prihvaćeno: 20. 11. 2019.

UDK: $630 * 812.582 ; 630 * 863.21$

https://doi.org/10.5552/drvind.2020.1909

(C) 2020 by the author(s) Licensee Faculty of Forestry, University of Zagreb. This article is an open access article distributed under the terms and conditions of the Creative Commons Attribution (CC BY 4.0) license.

\begin{abstract}
This study investigates the effects of types of adhesives on the combustion properties of oriented strand board panels (OSB). Combustion test was performed according to ASTM E69 standard. Mass reduction, change of temperature and released gas $\left(\mathrm{CO}, \mathrm{NO}, \mathrm{O}_{2}\right)$ were measured every 30 seconds during this test. Thermogravimetric analysis (TGA) of the OSBs was also carried out. While the highest temperature value of combustion was only obtained for the samples with phenol-formaldehyde at both outer and inner layer of test panels, the lowest temperature value was obtained for test samples with phenol-formaldehyde on the outer layer and isocyanate on the atinner layer. In the results of TGA, test mass reduction of OSBs was similar to each other, and most of the mass loss occurred at the temperatures between 200 and $400{ }^{\circ} \mathrm{C}$.
\end{abstract}

Key words: oriented strand board; combustion; thermo-gravimetric analysis; phenol-formaldehyde

SAŽETAK • U ovom su istraživanju ispitivani učinci različitih adheziva na svojstva gorenja ploča iverica s usmjerenim makroiverjem (OSB ploče). Ispitivanje gorenja provedeno je prema normi ASTM E69. Tijekom ispitivanja svakih je 30 sekundi mjereno smanjenje mase, promjena temperature i ispušteni plinovi (CO, NO, $\mathrm{O}_{2}$ ). Provedena je i termogravimetrijska analiza (TGA) OSB ploče. Dok su najveće vrijednosti temperature gorenja $u$ vanjskome i unutarnjem sloju ispitivanih ploča zabilježene samo na uzorcima s fenol-formaldehidom, najniža vrijednost temperature izmjerena je za ispitne uzorke s fenol-formaldehidom u vanjskom sloju i izocijanatom u unutarnjim slojevima. Po rezultatima TGA analize testovi smanjenja mase OSB ploča bili su međusobno slični, a najveći gubitak mase dogodio se pri temperaturama između 200 i $400{ }^{\circ} \mathrm{C}$.

Ključne riječi: ploča iverica s usmjerenim makroiverjem; gorenje; termogravimetrijska analiza; fenol-formaldehid

${ }^{1}$ Author is associate professor at Department of Industrial Engineering, Engineering Faculty, Ondokuz Mayıs University, Samsun, Turkey. 


\section{INTRODUCTION}

\section{UVOD}

Wood is a very good material - it is easy to shape, it has good physical and mechanical properties, aesthetics, and it is environmentally friendly. In many countries, it is widely used as a building material, and in some areas as main construction and decoration material (Bednarek and Kaliszuk, 2007). Oriented strand boards (OSB) are engineered materials, which were designed for replacing plywood or solid wood in structural components. So, these boards must have sufficient mechanical properties. To meet these requirements, high quality strands must be used in their production (Mayers, 2001). The durability of the OSB depends on many factors such as type of binding agent, processing conditions, and additive materials. The type of adhesive used in the production also has a serious effect on their properties. The resins typically used for OSB production include phenol-formaldehyde (PF), four component melamine-urea-phenol-formaldehyde resins (MUPF), and isocyanates (Methylene Diphenyl Diisocyanate - MDI) (Mirski et al., 2017). OSB is a one of the world's most commonly used particularly engineered wood-based panel products in residential areas (Hiziroglu, 2009) and in many applications of the construction industry. First advantages of OSB are its equivalent mechanical properties and substantially lower cost compared to structural plywood. When OSB is used in roof or wall sheathing, it is exposed to environmental factors and degradation (Gunduz et al., 2011). Plywood and OSB are used as structural sheathing. The use of the wood-based composite such as OSB has been increased since it is also widely used as the I-joints (White and Winandy, 2006).

One of the most negative features of the wooden materials is their combustibility. In order to eliminate this negative property of wooden materials, many chemicals are used to prevent their combustion and degradation. Many studies have been done with different combustion mechanisms on the combustion properties of wooden material. Fire tube mechanism is the most commonly used combustion mechanism. This mechanism is widely used and well-known in many countries (Ozcan et al., 2010). Uysal and Kurt (2005) have studied impregnation of Spruce (Picea orientalis L.) with boron compounds and the test samples that were applied to the combustion test. Uysal and Ozcifci (2000) have examined the combustion properties of laminated wood products made of different layers (both inner and outside) using PVAc adhesive.

During the first heat treatment process, many volatile organic compounds such as alcohols, resins, terpenes, etc. are released from the wood (Manninen et al., 2002). However, during this process, the decrease of hemicellulose content is not fully completed (Pavlo et al., 2003). The hemicellulose degrades between 160 and $260{ }^{\circ} \mathrm{C}$, since its low molecular weight and its branching structure facilitate a faster degradation when compared to the other components present in wood (Poncsak et al., 2006).
There are many important factors that affect physical and mechanical properties of wood composite materials. One of the most important factors is the type of adhesive used in production. Studies regarding resin content and type agree that increasing resin content or resin type can directly improve the stability by improving inter-particle bonding as it affects thickness swelling (Nemli, 2002). Although there are a lot of studies about the effects of resin types on physical and mechanical properties of particleboards, there is no adequate study on combustion and thermo-gravimetric properties of OSB. This paper focuses not only on the influence of adhesive types on combustion but also on the weight losses of OSBs during the thermo-gravimetric analysis (TGA).

\section{MATERIALS AND METHODS} 2. MATERIJALI I METODE

\subsection{Materials}

2.1. Materijali

Oriented strand board (OSB) test samples were manufactured from Scotch pine (Pinus sylvestris L.) wood. The used wood strands were approximately 80 $\mathrm{mm}$ long, $20 \mathrm{~mm}$ wide and $0.6 \mathrm{~mm}$ thick. First, the wood strands were dried up to $3 \%$ moisture content before the adhesive was sprayed on them. The strands in the panels were made in three layers, and the inner ones were directed vertically to the outer ones. Phenolformaldehyde (47\%) and isocyanate, without wax, were applied as adhesive materials to the oven-dried wood strands based on their $6 \%$ weight. Three types of OSB panels were produced.

The OSB test sample \#1 was only used with phenol-formaldehyde adhesive on both inner and outer layers. As for the OSB test samples \#2, while phenolformaldehyde was used on the outer layers, isocyanate adhesive was used on the inner layers. As for test samples \#3, while isocyanate was used on the outer layers, phenol-formaldehyde adhesive was used on the inner layers. All the test panels were pressed for $5 \mathrm{~min}$. at 40 $\mathrm{kg} / \mathrm{cm}^{2}$. The shelling ratio of the samples was $40 \%$ for inner and $60 \%$ for outer layers. All the test samples were pressed to a density of about $0.70 \mathrm{~g} / \mathrm{cm}^{3}$. The mats of OSBs were pressed in automatically controlled laboratory press plates heated at $(182 \pm 3){ }^{\circ} \mathrm{C}$.

\subsection{Methods \\ 2.2. Metode}

The test samples were conditioned in a climate room with a temperature of $(20 \pm 2){ }^{\circ} \mathrm{C}$ and relative humidity of $(65 \pm 5) \%$ until they reached the stable weight. Combustion test was carried out according to the principles of ASTM E69. However, some changes were made in the test stand. For this purpose, a digital balance having $0.01 \mathrm{~g}$ sensitivity was used for the determination of mass reduction of materials during the burning process. Butane gas was used for ignition flame of test samples. The gas flow is standard for all test samples, and namely the height of flame is $25 \mathrm{~cm}$ and the temperature is approximately $1000{ }^{\circ} \mathrm{C}$. The distance 


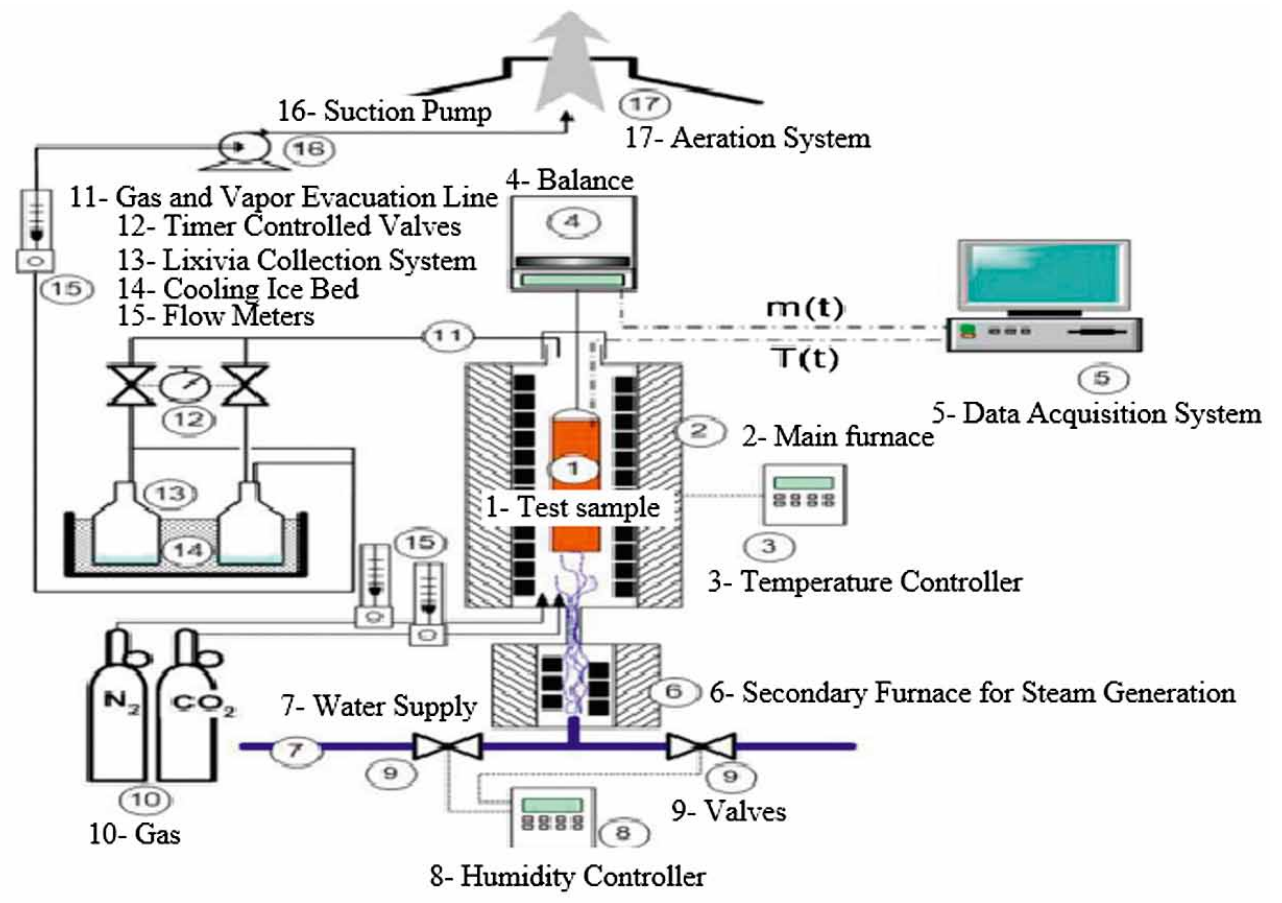

Figure 1 Schematic view of thermo-gravimetric system

Slika 1. Shematski prikaz termogravimetrijskog sustava (1 - ispitni uzorak; 2 - glavna peć; 3 - regulator temperature; 4 vaga; 5 - sustav za prikupljanje podataka; 6 - pomoćna peć za proizvodnju pare, 7 - opskrba vodom, 8 - regulator vlage, 9 - ventili, 10 - plin, 11 - linija za uklanjanje plina i pare, 12 - vremenski upravljani ventili, 13 - sustav za skupljanje Lixivia, 14 - ledena kupka, 15 - mjerači protoka, 16 - usisna pumpa, 17 - sustav za odzračivanje)

between the bottom of the test samples (which were hanged inside of the fire tube) and the top of the gas pipe are adjusted to $2.54 \mathrm{~cm}$.

During the test, release gases $\left(\mathrm{CO}, \mathrm{NO}, \mathrm{O}_{2}\right)$ and changes of the temperature were measured 20 times every 30 seconds. The test was conducted under a chimney where the flow of air blown was drawn with natural drift. At the beginning of combustion test, flame source was used for 4 minutes. Then, flame source was taken away and it took 6 minutes to make the measurements. Testo $350 \mathrm{M} \& X L$ flue gas analyzer was used for the measurement of the released gases and temperature variation.

The materials to be used in TGA, which weigh approximately $100 \mathrm{mg}$, were heated up to $800{ }^{\circ} \mathrm{C}$ in a nitrogen atmosphere at a rate of $10{ }^{\circ} \mathrm{C} / \mathrm{min}$ and mass losses due to temperature increase were determined. TGA setup (Figure 1) was built to study the effects of the heat treatment parameters (maximum treatment temperature, heating rate, holding time, and gas humidity) on the test sample quality.

The variation of the temperature distribution in the wood and the weight loss of the test samples were recorded during the analysis. The test samples were suspended on the balance of the furnace. A programmable temperature controller assured the desired evolution of temperature in the furnace. The inert gas mixture (nitrogen, carbon dioxide, and water vapour) was used in order to prevent the oxidation reactions in the furnace. Nitrogen and carbon dioxide flow rates were controlled with flow meters. The gas humidity was adjusted by using a second furnace, which was placed directly under the main furnace. The outlet gas is evac- uated from the system with a suction pump. An ice bed, as shown in Fig.1, was used to cool and collect condensed by-products, released from the test samples. Parallel lines, equipped with control valves, were used to separate condensed by-products collected at different temperature intervals.

Data obtained from experimental studies were statistically analyzed by using SPSS 20 program. First, distribution of the data was examined according to Test of Normality. Then descriptive statistics was performed.

\section{RESULTS AND DISCUSSION 3. REZULTATI I RASPRAVA}

The average air-density and moisture content values of OSBs were $0.72 \mathrm{~g} / \mathrm{cm}^{3}$ and $7.13 \%$, respectively. It can be said that the air-dry density and moisture content of test panels were found to be within the target limits. Results of the Test of Normality according to the Shapiro-Wilk are given in Table 1.

It can be seen that the changes in temperature and emerging gases, such as $\mathrm{CO}, \mathrm{NO}, \mathrm{O}_{2}$ obtained as a result of combustion tests, did not show normal distribution according to the Shapiro-Wilk. The results of the Descriptive Statistics (Min., Max., Mean, Std. Dev., Skewness and Kurtosis) for temperature, ratio of $\mathrm{O}_{2}$, $\mathrm{CO}$ and NO gases in the test chamber are shown in Table 2.

It is observed that the change of the temperature values is between $72{ }^{\circ} \mathrm{C}$ and $3021^{\circ} \mathrm{C}$. The higher temperatures were reached in the first $4 \mathrm{~min}$., as this the time when the flame is applied in the combustion test. 
Table 1 Test of normality

Tablica 1. Ispitivanje normalnosti raspodjele podataka

\begin{tabular}{|l|c|c|c|c|c|c|c|c|c|c|c|c|}
\hline & \multicolumn{3}{|c|}{$\begin{array}{c}\text { Temperature, } \\
\text { Temperatura }\end{array}{ }^{\circ} \mathrm{C}$} & \multicolumn{4}{|c|}{$\mathbf{O}_{\mathbf{2}}, \mathbf{\%}$} & \multicolumn{4}{c|}{ CO, ppm } & \multicolumn{3}{c|}{ NO, ppm } \\
\hline Type of panel / Vrsta panela & $\# 1$ & $\# 2$ & $\# 3$ & $\# 1$ & $\# 2$ & $\# 3$ & $\# 1$ & $\# 2$ & $\# 3$ & $\# 1$ & $\# 2$ & $\# 3$ \\
\hline Statistics/ Statistika & 0.35 & 0.91 & 0.90 & 0.88 & 0.74 & 0.84 & 0.90 & 0.79 & 0.86 & 0.84 & 0.78 & 0.84 \\
\hline$d f$ & 80 & 80 & 80 & 80 & 80 & 80 & 80 & 80 & 80 & 80 & 80 & 80 \\
\hline Significance / Značajnost & 0.00 & 0.00 & 0.00 & 0.00 & 0.00 & 0.00 & 0.00 & 0.00 & 0.00 & 0.00 & 0.00 & 0.00 \\
\hline
\end{tabular}

Table 2 Results of descriptive statistics

Tablica 2. Rezultati deskriptivne statistike

\begin{tabular}{|c|c|c|c|c|c|c|c|c|}
\hline \multirow{2}{*}{$\begin{array}{l}\text { Test parameters } \\
(\boldsymbol{N}=\mathbf{2 4 0}) \\
\text { Parametri ispiti- } \\
\text { vanja }\end{array}$} & \multirow{2}{*}{$\begin{array}{l}\text { Minimum } \\
\text { Minimum }\end{array}$} & \multirow{2}{*}{$\begin{array}{l}\text { Maximum } \\
\text { Maksimum }\end{array}$} & \multirow{2}{*}{$\begin{array}{c}\text { Mean } \\
\text { Srednja } \\
\text { vrijednost }\end{array}$} & \multirow{2}{*}{$\begin{array}{c}\text { Std. Deviation } \\
\text { Standardna } \\
\text { devijacija }\end{array}$} & \multicolumn{2}{|c|}{$\begin{array}{l}\text { Skewness } \\
\text { Asimetrija }\end{array}$} & \multicolumn{2}{|c|}{$\begin{array}{l}\text { Kurtosis } \\
\text { Kurtozija }\end{array}$} \\
\hline & & & & & Mean* & $\begin{array}{c}\text { Std. } \\
\text { Error** }\end{array}$ & Mean & $\begin{array}{l}\text { Std. } \\
\text { Error }\end{array}$ \\
\hline Temperature, ${ }^{\circ} \mathrm{C}$ & 72 & 3021 & 269.79 & 286.20 & 7.50 & 0.15 & 70.34 & 0.31 \\
\hline $\mathrm{O}_{2}, \%$ & 9.52 & 20.87 & 17.68 & 3.33 & -0.45 & 0.15 & -0.10 & 0.31 \\
\hline $\mathrm{CO}, \mathrm{ppm}$ & 83 & 4755 & 1708.68 & 1401.79 & 0.53 & 0.15 & -1.08 & 0.31 \\
\hline $\mathrm{NO}, \mathrm{ppm}$ & 5 & 195 & 55.27 & 52.79 & 0.89 & 0.15 & -0.34 & 0.31 \\
\hline
\end{tabular}

*Mean - srednja vrijednost $; *$ *Std. Error - standardna pogreška aritmetičke sredine

The average temperature is approximately $270{ }^{\circ} \mathrm{C}$ during the $10 \mathrm{~min}$. interval of the test. The average values of emergent gases $\left(\mathrm{O}_{2}, \mathrm{CO}, \mathrm{NO}\right)$ were found to be approximately $18 \%, 1708 \mathrm{ppm}$ and $55 \mathrm{ppm}$, respectively. Kruskal-Wallis test was applied (since there were three variables and data did not show normal distribution) in order to determine the effect of the type of adhesives on the values of temperature, $\mathrm{CO}, \mathrm{NO}$ and $\mathrm{O}_{2}$ emerged from combustion test of OSB panels. Result of the Kruskal-Wallis test is given in Table 3.
The results of Kruskal-Wallis test, which was performed according to the combustion test, show that the effect of the type of adhesive on the temperature and the amount of $\mathrm{CO}$ and $\mathrm{O}_{2}$ gases was significant, while the amount of NO gas was not statistically significant. Mann-Whitney U test was applied to determine which OSB test groups showed differences that occurred during the combustion tests (Table 4).

It is shown that, according to Mann-Whitney Utest, the effect of the adhesive type on the temperature

Table 3 Results of Kruskal-Wallis test

Tablica 3. Rezultati Kruskal-Wallisova testa

\begin{tabular}{|c|c|c|c|c|c|}
\hline \multirow{2}{*}{$\begin{array}{c}\text { Type of panel } \\
\text { Vrsta panela }\end{array}$} & \multicolumn{4}{|c|}{ Dependent Variables / Zavisne varijable } \\
\cline { 3 - 6 } & Temperature, ${ }^{\circ} \mathrm{C}$ & $\mathrm{CO}, \mathrm{ppm}$ & $\mathrm{NO}, \mathrm{ppm}$ & $\mathrm{O}_{2}, \%$ \\
\hline \multirow{2}{*}{$\begin{array}{c}\text { Mean Rank } \\
\text { Prosječni poredak }\end{array}$} & $\# 1$ & 111.53 & 148.43 & 126.28 & 97.48 \\
\cline { 2 - 6 } & $\# 2$ & 91.48 & 107.83 & 107.85 & 116.48 \\
\hline$X^{2}$ & $\# 3$ & 158.50 & 105.25 & 127.38 & 147.55 \\
\hline $\mathrm{P}$ & 39.29 & 19.47 & 4.00 & 21.22 \\
\hline
\end{tabular}

Table 4 Results of Mann-Whitney U-test

Tablica 4. Rezultati Mann-Whitneyjeva U-testa

\begin{tabular}{|c|c|c|c|c|c|}
\hline $\begin{array}{c}\text { Type of panels } \\
\text { Vrsta panela }\end{array}$ & & Temperature, ${ }^{\circ} \mathrm{C}$ & CO, ppm & NO, ppm & $\mathbf{O}_{2}, \%$ \\
\hline \multirow{4}{*}{$\# 1$ and \#2 } & Mann-Whitney U & 2592 & 2026 & 2698 & 2560 \\
\hline & Wilcoxon W & 5832 & 5266 & 5938 & 5800 \\
\hline & $\mathrm{Z}$ & -2.08 & -4.01 & -1.72 & -2.18 \\
\hline & $\begin{array}{l}\text { Asymp. Sig. } \\
\text { (2-tailed) }\end{array}$ & 0.04 & 0.00 & 0.09 & 0.03 \\
\hline \multirow{4}{*}{$\# 1$ and $\# 3$} & Mann-Whitney U & 1874 & 2140 & 3160 & 1998 \\
\hline & Wilcoxon W & 5114 & 5380 & 6400 & 5238 \\
\hline & $\mathrm{Z}$ & -4.53 & -3.62 & -0.14 & -4.10 \\
\hline & $\begin{array}{l}\text { Asymp. Sig. } \\
\text { (2-tailed) }\end{array}$ & 0.00 & 0.00 & 0.89 & 0.00 \\
\hline \multirow{4}{*}{$\# 2$ and $\# 3$} & Mann-Whitney U & 1486 & 3040 & 2690 & 2238 \\
\hline & Wilcoxon W & 4726 & 6280 & 5930 & 5478 \\
\hline & $\mathrm{Z}$ & -5.85 & -0.55 & -1.74 & -3.28 \\
\hline & $\begin{array}{c}\text { Asymp. Sig. } \\
\text { (2-tailed) }\end{array}$ & 0.00 & 0.59 & 0.08 & 0.00 \\
\hline
\end{tabular}




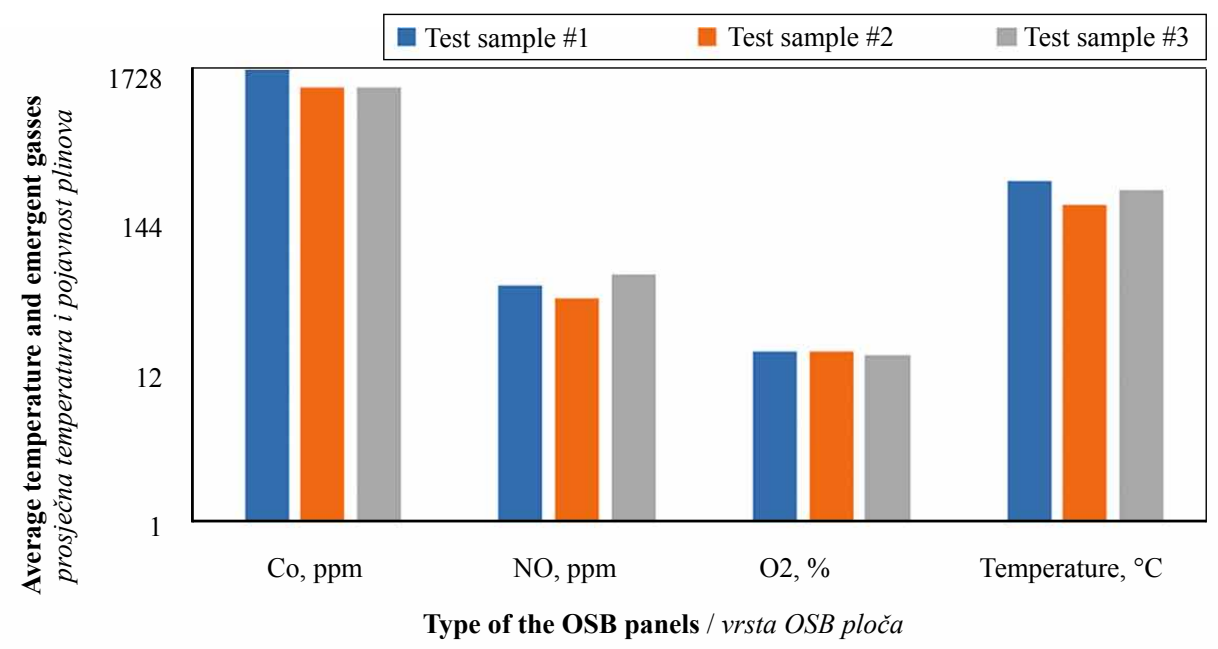

Figure 2 Change of $\mathrm{CO}, \mathrm{NO}, \mathrm{O}_{2}$ and temperature

Slika 2. Promjena $\mathrm{CO}, \mathrm{NO}, \mathrm{O}_{2}$ i temperature

and the amount of $\mathrm{O}_{2}$ gas obtained from the combustion tests was significant in the test groups of test panels \#1 \& \#2, \#1 \& \#3 and \#2 \& \#3, whereas the effect of the adhesive type on the amount of NO gas was not significant. The average values of temperature and emergent gases ratio are shown in Figure 1.

The highest CO value of 2081.65 ppm was obtained from the Test Sample \#1, and the lowest value was measured as 1519.43 ppm from the Test Sample \#3. The highest level of temperature was $317.23{ }^{\circ} \mathrm{C}$ from the Test Sample \#1, produced by using only phenol-formaldehyde adhesive. As a result of combustion test, the highest value of $\mathrm{O}_{2}$ was $(18.39 \%)$ obtained from the Test Sample \#2. The average value of $\mathrm{NO}$ gas ranged between 44.73 and $66.15 \mathrm{ppm}$ in this experimental study. All the results connected with these values are shown in Figure 1.

TGA is one of the most common techniques used to evaluate thermal behaviour during the pyrolysis of wood and other biomasses (Ertas and Alma, 2010; Ozbay, 2015). The mass reductions related to heat temperature used in thermo-gravimetric analyses is shown in
Figure 2. It was determined that, as a result of gravimetric analysis of test panels, the weight losses of three different panels were similar and about $98 \%$. The reduction of mass turned out to be $98.44 \%$ in the Test Sample \#1 (first panel). Moreover, it was also identified that the mass reduction of the Test Sample \#2 (second panel) was $98.07 \%$. In addition to this, it was measured that the mass reduction of the Test Sample \#3 (third panel) was very close to the second panel $(98.01 \%)$.

Insoluble compounds act as a heat sink that decreases the combustion efficiency, but the soluble ionic compound can have a catalytic effect on the pyrolysis and combustion of wood (Shafizadeh, 1981). Song and Rao (1999) searched the effects of heat on constructional properties of plywood treated with fire retardant materials. Due to the increased use of wood-based composites such as OSBs, it becomes important to assess their fire performance after exposure to high temperatures. Since they are less massive than solid wood, they are less likely to resist a rapid temperature rise (Sinha et al., 2009). So, further study on the effect of high temperature on various properties of wood-based

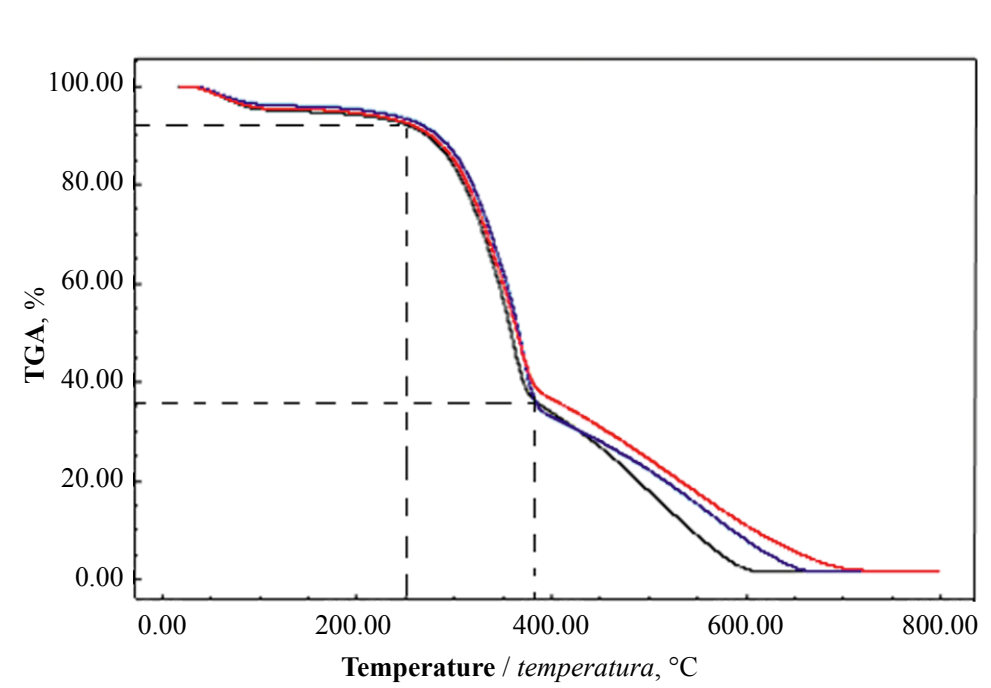

\begin{tabular}{|lc|}
\hline \multicolumn{2}{|c|}{ First panel } \\
Mid Point & $357.42 \mathrm{C}$ \\
Onset & $301.75 \mathrm{C}$ \\
Endset & $413.94 \mathrm{C}$ \\
Weight Loss & $-8.140 \mathrm{mg}$ \\
& $-98.440 \%$ \\
\multicolumn{3}{|c}{ Second panel } \\
Mid Point & $362.40 \mathrm{C}$ \\
Onset & $320.76 \mathrm{C}$ \\
Endset & $412.71 \mathrm{C}$ \\
Weight Loss & $-7.345 \mathrm{mg}$ \\
\multicolumn{3}{|c}{$-98.077 \%$} \\
Third panel \\
\hline Mid Point & $362.76 \mathrm{C}$ \\
Onset & $304.81 \mathrm{C}$ \\
Endset & $419.91 \mathrm{C}$ \\
Weight Loss & $-8.237 \mathrm{mg}$ \\
\multicolumn{2}{c}{$-99.001 \%$} \\
\hline
\end{tabular}

Figure 3 Mass reduction of panel related to heat temperature

Slika 3. Smanjenje mase ploče s obzirom na temperaturu zagrijavanja 
composites is needed. Such thermal degradation studies involve understanding and predicting the behaviour of wood-based materials during their exposure to high temperatures.

They stated that the maximum mass reduction was between $300-380{ }^{\circ} \mathrm{C}$ after TGA tests. In addition, according to TGA, which was applied on OSB panels produced by using Scotch pine chips, the highest mass reduction was between $280-320{ }^{\circ} \mathrm{C}$. The mass reduction obtained in the study is compatible with the literature, e.g. Tutus et al., (2010) stated that thermal degradation of Scots pine occurred between 300 and $500{ }^{\circ} \mathrm{C}$.

\section{CONCLUSIONS}

4. ZAKLJUČAK

There are many studies in the literature that focus on the increase of the resistance of wood composite materials against environmental factors, and on the mechanical and physical properties of wood composite materials. This study investigated the combustion and thermo-gravimetric analysis of oriented strand boards manufactured from Scotch pine wood. So, this study is a preliminary work on the combustion and TGA of OSB panels. According to the results of combustion tests, the gas outcomes and changes of temperature are measured approximately as $17.68 \%$ for $\mathrm{O}_{2}, 1708.66 \mathrm{ppm}$ for $\mathrm{CO}$, $55.27 \mathrm{ppm}$ for $\mathrm{NO}$ and $269.79^{\circ} \mathrm{C}$. The mass reduction of test specimens was measured between $250-400{ }^{\circ} \mathrm{C}$ according to the results of TGA. The reason of the mass reduction at this range could be possible because of the degradation of wood components. It can be seen that the adhesive types used in the production of test panels have a considerable impact on similar properties in terms of mass loss according to the TGA test.

\section{REFERENCES}

\section{LITERATURA}

1. Bednarek, Z. A.; Kaliszuk, W. A., 2007: Analysis of the Fire-Protection Impregnation Influence on Wood Strength. Journal of Civil Engineering and Management, 13 (2): 7985. https://doi.org/10.3846/13923730.2007.9636423.

2. 2. Ertas, M.; Alma, H. M., 2010: Pyrolysis of laurel (Laurus nobilis L.) extraction residues in a fixed-bed reactor: Characterization of bio-oil and bio-char. Journal of Analytical and Applied Pyrolysis, 88: 22-29. https://doi.org/10.1016/j.jaap.2010.02.006.

3. Gunduz, G.; Yapıc1, F.; Ozcifci, A., 2011: The Effects of Adhesive Ratio and Pressure Time on Some Properties of Oriented Strand Board. BioResources, 6 (2): 2118-2124. https://doi.org/10.15376/biores.6.2.2118-2124.

4. Hiziroglu, S., 2009: Properties of Strandboard Panels Manufactured from Eastern Redcedar. Materials, 2 (3): 926-933. https://doi.org/10.3390/ma2030926.

5. Manninen, A. M.; Pasanen, P.; Holopainen, J. K., 2002: Comparing the VOC emission between air-dried and heat-treated Scots pine wood. Atmospheric Environment, 36: 1763-1768. https://doi.org/10.1016/s1352-2310(02)00152-8.

6. Mayers, K. L., 2001: Impact of Strand Geometry and Orientation on Mechanical Properties of Strand Compos- ites. Master's Thesis, Washington State University, Pullman, WA, USA.

7. Mirski, R.; Dziurka, D.; Derkowski, A., 2017: Dimensional stability of oriented strand boards with external layers made of non-strand chips: Changes in board length. BioResources, 12 (4), 7107-7117.

https://doi.org/10.15376/biores.12.4.7107-7117.

8. Nemli, G., 2002: Factors Affecting the Production of E1 Type Particleboard. Turkish Journal of Agriculture and Foresty, 26 (1): 31-36. http://journals.tubitak.gov.tr/agriculture/issues/tar-02-26-1/tar-26-1-5-0009-7.pdf.

9. Ozbay, G., 2015: Pyrolysis of firewood (Abies bornmülleriana Mattf.) sawdust: characterization of bio-oil and bio-char. Drvna industrija, 66 (2): 105-114. https://doi.org/10.5552/drind.2015.1359.

10. Ozcan, C.; Bayir, R., Ozcan, C., 2010: Monitoring of Wooden Material Combustion Performance with Fuzzy Logic. Technology, 13 (3): 189-199.

11. Pavlo, B.; Niemz, P., 2003: Effect of High Temperature on the Change in Color, Dimensional Stability and Mechanical Properties of Spruce Wood. Holzforschung, 57 (5): 539-546. https://doi.org/10.1515/HF.2003.080.

12. Poncsak, S.; Kocaefe, D.; Bouazara, M.; Pichette, A., 2006: Effect of high temperature on the mechanical properties of birch (Betula papyrifera). Wood Science Technology, 40 (8): 647-663.

https://doi.org/10.1007/s00226-006-0082-9.

13. Shafizadeh, F., 1981: Basic Principles of Direct Combustion, in Biomass Conversion Process for Energy and $\mathrm{Fu}-$ els. Sofer, S. S. (eds.). Press Plenum Publishing, New York: 103-124. https://doi.org/10.1007/978-1-4757-0301-6_6.

14. Sinha, A.; Nairn, J. A.; Gupta, R., 2009: Thermal degradation of bending strength of plywood and oriented strand board: a kinetics approach. Wood Science and Technology, 45 (2): 315-330. https://doi.org/10.1007/s00226-010-0329-3.

15. Song, Y. W.; Rao, Y. C., 1999: Structural Performance of Fire- Retardant Treated Playwood: Effect of Elevated Temperature. Holzforschung, 53 (5): 547-552. https://doi.org/10.1515/hf.1999.090.

16. Tutus, A.; Kurt, R.; Alma, M. H.; Meric, H., 2010: Chemical analysis and thermal properties of pine wood. III. Ulusal Karadeniz Forestry Congress, vol. 5: 1845-1851, Turkey. http://karok3.artvin.edu.tr/V.Cilt/(1845-1851).pdf (2019).

17. Uysal, B.; Kurt, S., 2005: Combustion Properties of Spruce Tree Impregnated with Boron Compounds. Ladin Symposium, Proceedings Book, II-845, Trabzon, Turkey.

18. Uysal, B.; Ozcifci, A., 2000: Combustion Properties of Laminated Wood Material Produced with PVAc Adhesive from Uludağ Fir (Abies bornmülleriana Mattf). Journal of Polytechnic, 3 (1): 23-29.

19. White, R. H.; Winandy, J. E., 2006: Fire performance of oriented strandboard. Seventeenth Annual BCC Conferences on Flame Retardancy. https://www.researchgate.net/publication/237791769.

\section{Corresponding address:}

Assoc. Prof. Fatih YAPICI, Ph.D.

Department of Industrial Engineering

Engineering Faculty

Ondokuz Mayıs University

Samsun, TURKEY

e-mail: fatih.yapici@omu.edu.tr 